Pregledni naučni rad

Primljeno: 23. 9. 2016.

UDK: 343.982 .34

Revidirana verzija: 21.10 .2016$.

Prihvaćeno: 25. 10. 2016.

\title{
POLYMERS IN CRIMINALISTICS: LATENT FINGERPRINT DETECTION AND ENHANCEMENT - FROM IDEA TO PRACTICAL APPLICATION
}

\author{
Nikola Milašinović ${ }^{1}$ \\ Academy of Criminalistic and Police Studies, Belgrade
}

Summary: The identification of latent fingerprints is crucial for the security agencies in order to identify persons suspected of having committed criminal acts. Latent prints often remain as random impressions onto the surfaces of various objects. Huge progress has been made in the identification processes using rolled and plain impressions fingerprints, while detection and comparison of latent prints still remains a challenging task. In addition to the existing standardized methods, in this paper the possible utilization of natural and synthetic polymers and their conjugates with the same goal will be reviewed, by means of latent fingerprints detection and development.

Keywords: Identification, Latent Fingerprints Development and Detection Methods, (Bio)polymers, Chitosan.

\section{Introduction}

Identification of latent fingerprints is crucial for law enforcement agencies in identifying suspected persons. ${ }^{2}$ Nowadays, many different methods for revealing and developing the latent fingerprints have been used. The utilization

1 Assistant Professor; nikola.milasinovic@kpa.edu.rs

2 B Sundarraj, Untapped Fingerprint Matching Using Advanced Features, Middle-East Journal of Scientific Research, Vol. 19 Nº/2014, p. 826-833. 
of powders (especially for non-porous surfaces) is one of the simplest and most commonly used methods for fingerprints detection. ${ }^{3}$ Both in practice and for scientific purposes various proven methods, such are ninhydrin, iodine fuming methods, cyanoacrylate fuming methods, usually followed by treatment with fluorescent staining solutions, silver nitrate method, sticky-side powder, and gentian violet stain, physical developers have already been used, while each single method gives different results. ${ }^{4,5,6,7}$

However, none of these methods offers ideal results, and researchers are still very interested in finding new detection, enhancement and fixing methods of latent traces. To support further research, the fact that not all materials are good enough for the use of certain methods, the use of different (multi) methods of detection and identification is always recommended. In addition to the well-known methods of detection and identification of latent papillae traces, the use of polymers, in particular biopolymers, is still not sufficiently investigated, and the scientific community is almost not aware of the potential applications of these materials with the previously mentioned purpose.

\section{Polymer-based Conjugates as Systems for Latent Fingerprints Development and Detection}

The materials that go through changes of color in response to the external physical (heat, light, pressure, electricity) and the chemical/biochemical (solvent, $\mathrm{pH}$, ligand-receptor interaction) stimuli may be used as key components sensors, switches or memory devices. ${ }^{8,9,10}$ Among colorimetric substances sensitive to external stimuli tested so far, conjugated polymers have attracted certain attention due to their unique optical properties associated with the

3 C. Lennard, ; The Detection and Enhancement of Latent Fingerprints, 13th INTERPOL Forensic Science Symposium, Lyon, France, 2001, p 212.

4 H. Lee, Advances in Fingerprint Technology ( $2^{\text {nd }}$ Ed. $)$. Boca Raton, Florida: CRC press, 2001. 5 C. Champod, Fingerprints and other Ridge Skin Impressions. Boca Raton, Florida: CRC Press, 2004, p. 237-244.

6 T. Kubic,; N. Petraco, Forensic Science Manual and Workbook (Revised Ed.). Boca Raton, Florida: CRC press, 2005., 43-45

7 B. McCord, Forensic Chemistry, Laboratory Manual, Revision 7.1. Department of Chemistry, Florida International University, 2005, p. 46-61.

8 J. Lee, et al., Hydrochromic conjugated polymers for human sweat pore mapping.p. 212. 9 W. Li, et al., Recent Advances in Stimuli-Responsive Photofunctional Materials Based on Accommodation of Chromophore into Layered Double Hydroxide Nanogallery, Journal of Nanomaterials, Article ID 586462, 14 pages, 2013.

10 E. Mastronardi, et al., Smart Materials Based on DNA Aptamers: Taking Aptasensing to the Next Level, Sensors, Vol. 14 N²/2014, p. 3156-31. 
presence of delocalized $\pi$-electrons. ${ }^{11}$ When localized stimulation of conjugated polymers results in a change in the absorption and emission characteristics, these materials could have been effectively used as sensor matrices. ${ }^{12},{ }^{13}$

As written in the article published in Nature Communications ${ }^{14}$ a polymer that exhibits instantaneous fluorescence and color change in response to a small amount of water can be useful material for individual sweat pores detection. It has been confirmed that this method is sensitive enough to detect individual sweat pores of a human hand that leads to detailed color prints. The idea of using sweat pores in order to detect latent fingerprints was proposed earlier, but cheap, fast and reliable methods of pores mapping are still difficult to achieve. Jong-Man Kim et al. ${ }^{15}$ described a simple polymer-based material that gives an immediate, sensitive enough response to distinguish functional pores of those that are inactive (Figure 1) when finger was presented.

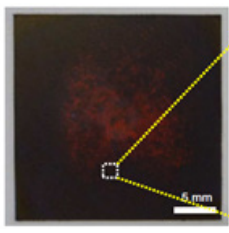

(a)

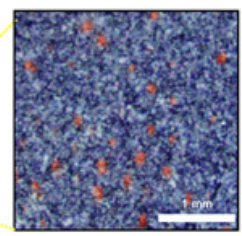

(b)

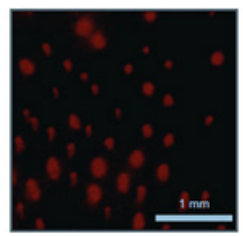

(c)

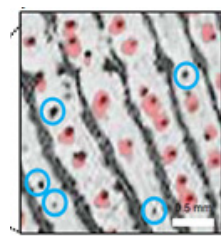

(d)

Figure 1. Mapping of sweat pores. (A) Photograph of a fingerprint on poly (10,12-pentacosadiynoic acid-cesium (PCDA-Cs)) film (thickness about $3.8 \mathrm{~mm}$ ); (B) optical and (c) fluorescence micrograph of magnified area in the image (a) obtained with excitation at $510-550 \mathrm{~nm}$; (D) images with increased contrast - dots inside the blue circles are pores that do not secrete sweat. ${ }^{1}$

As known, the ridges are generally used for inducing fingerprints, but a reliable analysis sometimes requires large print portions. Sweat pores allow identification of a pattern and with very small part of the latent trace, suggesting that this method can be used as a reliable method for detection of latent fingerprints. Mapping of active sweat pores was performed by using a fluorescent microscope excitation at $510-550 \mathrm{~nm}$. Unlike conventional methods, which largely depend on the friction of papillae ridges over the surface, and thus require large areas of latent prints for reliable analysis, the proposed

11 K. Molapo, et al., Electronics of Conjugated Polymers (I): Polyaniline, International Journal of Electrochemical Science, Vol. 7, No 1/2012, p. 11859-11875

12 J. Lee, et al., Opus citatum, p. 2.

13 P. Altamura,et al., Electrical and morphological characterisation of new $\pi$-conjugated polymer films as gas sensors, Materials Science and Engineering: C, Vol. 5, № 3-4/1998, p. $217-221$

14 Chemical sciences: Polymers for fingerprint analysis, available at: http://www.natureasia.com/en/research/highlight/9256/ (September 23, 2016.)

15J. Lee, et al., Opus citatum, p. 5. 
method can be used to identify even when there is a relatively small portion of latent fingerprint. ${ }^{16}$

In order to achieve stable and improved performance of the synthesized system (conjugate), and thus to obtain the efficient transfer of electrons, good color retention, good photosensitivity and high photostability, the researchers more often apply the immobilization of an active ingredient (usually different colors) conjugates into a various materials (carriers), such are hydrophobic bentonite particles ${ }^{17}$ or hydrogels. ${ }^{18}$ For instance, some fluorescence positively charged dyes, Rhodamine 6G (R6G) or Methylene Blue (MB), showing different fluorescence lifetime ${ }^{19}$ may be suitable as an agent for developing the latent fingerprints in forensics. ${ }^{20}$

The polymer surfaces play an important role in many technological processes, such as catalysis, corrosion or adhesion..$^{21}$ These processes depend on the chemical composition of the surface but also on the analytical techniques (spectroscopy or microscopy), with an aim of the characterization of the surface chemical composition. ${ }^{22}$ Yu-Juan et al. ${ }^{23}$ synthesized uniformed and well dispersed photoluminescent semiconductor cadmium sulfide (CdS) quantum dots in situ within 4.0 Generation- $\mathrm{NH}_{2}$ polyamidoamine (PAMAM) dendrimers in methanol and a mixture of methanol and water in a volume ratio of 1:9 respectively, used to detect cyanoacrylate ester fumed/deposited fingerprints on tinfoil. When applying the ultraviolet excitation of $365 \mathrm{~nm}$ a light yellow-green and orange luminescence appears (Figure 2) respectively, and fumed fingerprints were successfully detected with completely described reaction mechanism. ${ }^{24}$

\section{Ibidem, p. 3.}

17 Q. Chen,et al., TApplication of dye intercalated bentonite for developing latent fingerprints, Applied Clay Science, Vol. 44, No 1-2/2009, p. 156-160

18 E. Hermosilla -Araya, et al., Immobilization of rhodamine 6G in calcium alginate microcapsules based on aromatic-aromatic interactions with poly(sodium 4-styrenesulfonate), Reactive \& Functional Polymers, Vol. 81, No 1/2014, p. 14-21.

19 B. Fujimoto, et al., Fluorescence and Photobleaching Studies of Methylene Blue Binding to DNA, Journal of Physical Chemistry, Vol. 98, № 26/1994, p. 6633-6643

$20 \mathrm{G}$. Payne, et al., A further study to investigate the detection and enhancement of latent fingerprints using visible absorption and luminescence chemical imaging, Forensic Science International, Vol. 150, $\mathrm{N}^{\circ} 1 / 2005$, p. 33-51.

21 C. M. Jecklin, G. Gamez, R. Zenobi, Fast polymer fingerprinting using flowing afterglow atmospheric pressure glow discharge mass spectrometry, Vol. 134, No 8/2009, p.

22 K. S. Chowdhury, M. Doleman, D. Johnston, ., Fingerprinting Proteins Coupled with Polymers by Mass Spectrometry: Investigation of Polyethylene Glycol-Conjugated Superoxide Dismutase, Journal of the American Society for Mass Spectrometry, Vol. 6, № 1/1995, p.478-487

23 J. Yu-Juan, et al., Application of photoluminescent CdS/PAMAM nanocomposites in fingerprint detection, Forensic Science International Vol. 179, № 1/2008, p. 34-38

$24 \mathrm{H}$. L. Hanus, et al., Aggregation kinetics of dendrimer-stabilized CdS nanoclusters, Langmuir 10 Vol. 16, № 1/2000, p. 2621-2626 
These systems have recently attracted huge attention as they possess unique optical properties due to the effect of quantum restrictions because of its structure. CdS quantum dots are one of the most investigated semiconductors as they possess unique chemical, physical and optoelectronic properties which make them potentially useful in microelectronics, catalysis and bioanalytical applications. ${ }^{25}$

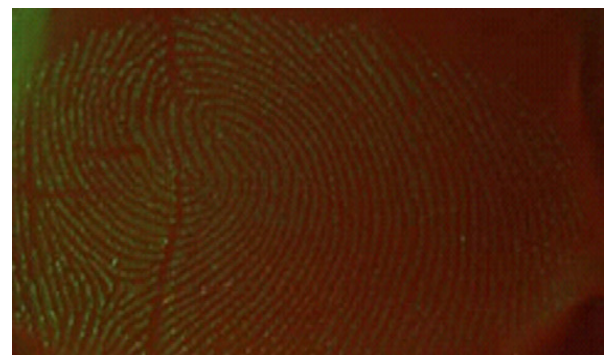

(a)

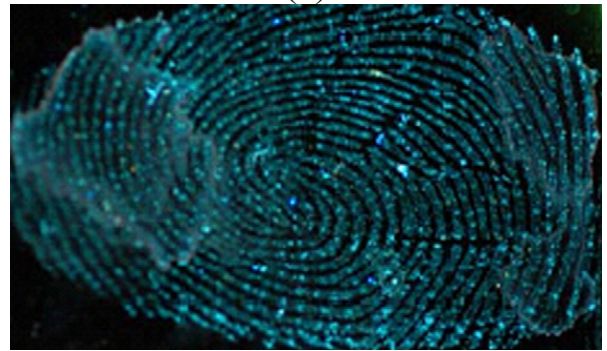

(c)

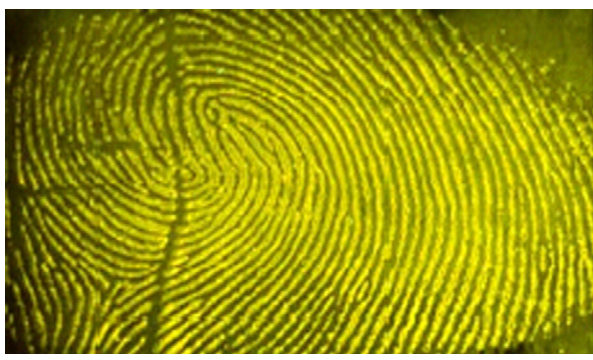

(b)

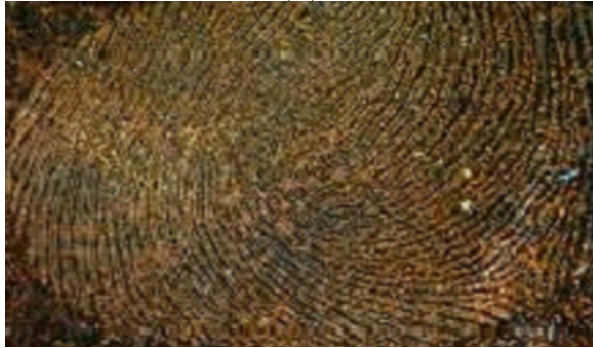

(d)

Figure 2. Fingerprint left on the tinfoil, fumed with cyanoacrylate ester fumes a) CdS/G4.0 PAMAM nanocomposite; b) CdS/G4.0 PAMAM nanocomposite in a methanol solution; c) CdS/G4.0 PAMAM nanocomposite in a methanol : water (1:9) solution; and d) CdS/ mercaptoacetic nanocomposite in water solution (without additional yellow filter), taken with a digital camera (Nikon D80) with the assistant of a yellow light filters. ${ }^{23}$

$\mathrm{CdS} /$ dendrimer nanocomposites can be useful for the production of new optical sensors, microelectronic devices and luminescent biological probes, ${ }^{26}$ and their application is justified in terms of selective latent prints labeling, with both physical and chemical mechanisms, with adjustable excitation and color luminescence by synthesis of nanocrystals of desired size having strong luminescence. The fumed fingerprints can be detected more efficiently than when applying traditional $\mathrm{CdS} / 2$-mercaptoethanol nanocomposites.

25 J. Yu-Juan, et al., Opus citatum, p. 35.

26 Ibidem, p. 4. 
Dilag et al. examined the possibility of applying high photoluminescent CdS quantum dots encapsulated in a cheap chitosan polymer matrice for detection of latent fingerprints. ${ }^{27}$ Quantum dots represent semiconductor nanocrystals that have optical and electrical characteristics that depend on particle size due to the effect of quantum limitations. ${ }^{28}$ Cadmium ions are chelated within a chitosan matrice by rapid addition of sodium sulfide to form particles of CdS/ chitosan nanocomposite. ${ }^{29}$ Fresh deposited non-fumed cyanoacrylate latent fingerprint on the aluminum foil was clearly observed under Rofin ${ }^{30}$ light at $450 \mathrm{~nm}$ when spattered with prepared suspension together with surfactant $\left(\right.$ Tergitol $^{31}$ ), allowing formation of powder surfactant/quantum dot (Figure 3).
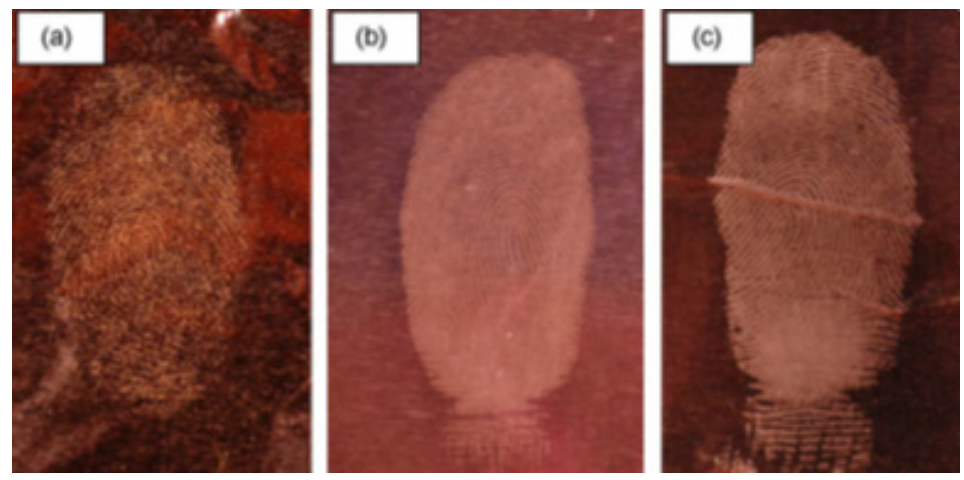

Figure 3. Photos of latent fingerprints on the aluminum foil surface spattered using (a) powdered quantum dots, (b) white powder, and (c) aluminum powder 9

Quantum dots powder has been successfully used to develop latent fingerprints on aluminum foil, with distinctive characteristics of the ridges.

Furthermore, chitosan is very much used in the preparation of microparticles for sustained release of the active substances. However, its utilization in forensic applications has not been studied enough so far. Issa et al. ${ }^{32}$ examined

27 J. Dilag, H. Kobus, V. A. Ellis, Cadmium sulfide quantum dot/chitosan nanocomposites for latent fingermark detection, Forensic Science International 187, 97-102 (2009).

28 G. Cao, Nanostructures and Nanomaterials Synthesis, Properties and Applications, Imperial College Press, UK, 2004, p. 371-372.

29 Ibidem, p 5.

30 http://www.crime-scene.com/store/rofin_polilight_flare.shtml_(September 23, 2016.) $31 \mathrm{http}: / / \mathrm{msdssearch.dow.com/PublishedLiteratureDOWCOM/dh}$ 00ae/0901b803800aea3b.pdf?filepath=surfactants/pdfs/noreg/119-01950.pdf\&fromPage $=$ GetDoc $($ September 23, 2016.)

32 M. A. Issa, I Dueik, G. A. Morris, ., Latent Fingerprint Enhancement Using Tripolyphosphate-Chitosan Microparticles, International Journal of Carbohydrate Chemistry, Vol. 2013, Article ID 615124, 4 pages, http://dx.doi.org/10.1155/2013/615124 
the possibility of application of chitosan microparticles crosslinked with sodium tripolyphosphate (TPP) in the presence of red color, to ensure better visualization, deposited on the latent fingerprints enabling their identification, by binding of synthesized microparticles to fatty acids residues of latent fingerprints (Figure 4).

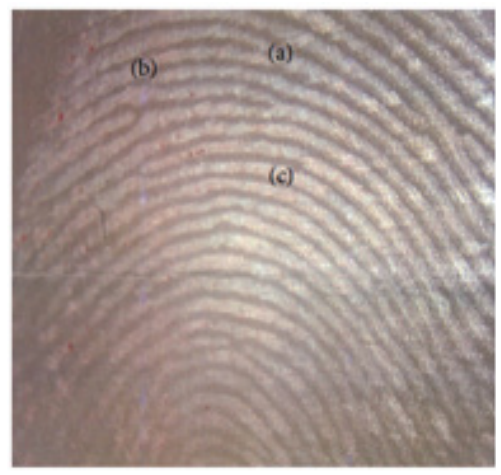

Figure 4. A latent fingerprint treated with TPP-chitosan microparticles (in the ratio 4:1). Some common features used for entification (a) edges, (b) bifurcations and (c) crossovers were specified. ${ }^{33}$

It points to the fact that a large number of factors influence the effectiveness of the application of the proposed system, such as the degree of deacetylation of chitosan, chitosan/TPP ratio, storage temperature, molar mass, charge, etc. ${ }^{34}$

Lipophilic, polycationic polymer, chitosan, can be used as substrate for latent fingerprints detection. Chitosan is the second most abundant natural polymer, and according to the literature data, it is mainly used as a carrier for various active components. ${ }^{35}$ The scientific community is aware of the fact that chitosan can also be used for the deposition of gold nanoparticles, and Islam et al. ${ }^{36}$ examined the possibility of application of the proposed system for detection of latent fingerprints (Figure 5). In this way cheap but effective improvement of the optical contrast was achieved, which greatly facilitated the identification process itself.

33 L. M. Tsai, .et al, The storage stability of chitosan/tripolyphosphate nanoparticles in a phosphate buffer, Carbohydrate Polymers, Vol. 84, №2/2011, p. 756-761.

34 L. M. Tsai, .et al, Opus citatum, p. 6.

$35 \mathrm{~K}$. Trifković, et al., Chitosan microbeads for encapsulation of thyme (Thymus serpyllum L.) polyphenols, Carbohydrate Polymers. Vol. 111, №1/2014, p. 901-907.

36 U. N. Islam, et al., Forensic Fingerprint Enhancement using Bioadhesive Chitosan and Gold Nanoparticles, Proceedings of the 2nd IEEE International Conference on Nano/Micro Engineered and Molecular Systems, January 16-19, 2007, Bangkok, Thailand, p. 411-415. 
About $99 \%$ of the fingerprints represents water, which evaporates very quickly leaving behind the remains of the order of micrograms. About half of these residues are complex mixtures of organic substances such as fats, amino acids, vitamins, etc. ${ }^{37}$ Schnetz and Margot ${ }^{38}$ were the first to report the possibility of using gold nanoparticles that depended on a large number of parameters, both on the porous and non-porous surfaces, but the reaction mechanism of gold nanoparticles with the sweat residues was not entirely determined. This technique has been significantly improved by Islam et al., and the synthesized system was applied in order to bind chitosan to fats which remain in a latent (finger)print.
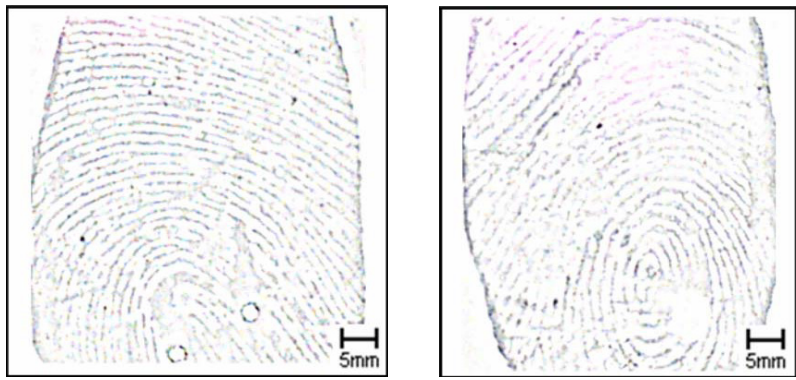

Figure 5. The developed latent fingerprints with varying amounts of residues collected from different individuals by applying the proposed (optimized) method. ${ }^{37}$

This method represents a non-destructive method, while at the same time the removal of any of the characteristics of physical evidence was avoided. In comparison with more developed techniques for fingerprints detection, such as gas chromatography, mass spectrometry, X-ray fluorescence, elemental analysis, the degree of identification does not depend on the material being used. An excellent contrast is obtained when applying $1 \%$ chitosan solution after 30 minutes, and its further development in the agglomerated colloidal solution of gold, for the period of 6-7 hours. The resulting contrast clearly differentiated the ridges, and hence this method has the potential to be applied for forensic identification. ${ }^{39}$

Almong et al..$^{40}$ examined the potential application of genipin, the hydrolytic product of geniposide extracted from gardenia fruit, as a reagent for detection of latent fingerprints found on the brown wrapping paper. One of the great

37 U. N. Islam, et al., Ibidem, p. 6.

38 B. Schnetz, P. Margot, Technical Note: Latent fingermarks, colloidal gold and multimetal deposition (MMD) optimization of the method, Forensic Science International, Vol. $118, \mathrm{~N}^{\circ} 1 / 2001$, p. $21-28$.

39 B. Schnetz, P. Margot, Ibidem, p. 6.

40 J. Almog, et al., Ibidem, p. 7. 
advantages of genipin is the fact that it is completely harmless and environmentally friendly reagent ${ }^{41}$ and developed fingerprints appear as blue traces (impressions) that fluoresce when exposed to the UV light of wavelength $590 \mathrm{~nm} .{ }^{42}$

The same research team examined the optimal conditions for genipin utilization taking into account the presence of a different solvent, concentration, temperature, humidity of the surroundings and the heating mode. The possibility of sequential developing of traces was also examined by using 1,8-diazafluoren-9-one (DFO) and ninhydrin ${ }^{43}$ and the obtained results were compared in terms of performance, and the spectrofluorometric data of reaction of genipin with several amino acids were generated. The circumstances under which genipin takes precedence over DFO and ninhydrin were specified, like on the brown wrapping paper or on documents written using fluorescent dye (Figure 6).

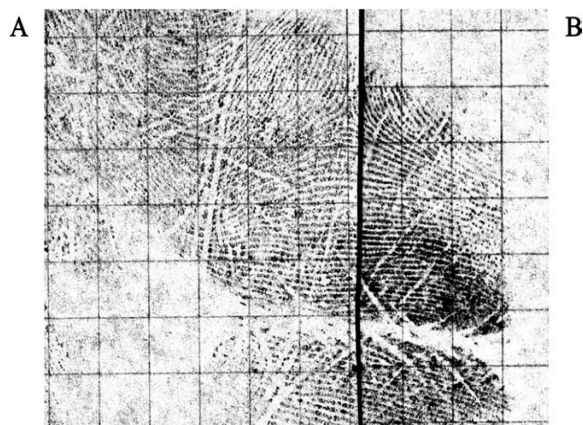

(a)

(b)

Figure 6. Half palmprints developed on notebook paper by using (a) genipin and (b) ninhydrin, recorded under white light.

It is well documented fact that DFO is more sensitive to amino acids than ninhydrin, and that its use is recommended in series with ninhydrin, but before ninhydrin application. ${ }^{44}$ Unlike ninhydrin, the reaction mechanism of DFO and its analogs (Figure 7) have not gained much attention since its introduction in forensic application. ${ }^{45}$

41 https://www.wou.edu/las/physci/ch350/Projects_2006/Vaandering/Genipin.htm (September 23, 2016.)

42 A. Lendlein, et al., Light-induced shape-memory polymers, Nature Vol. 434, № 1/2005, p. 879-882.

43 G. Shamuilov -Levinton, et al., Genipin, a Novel Fingerprint Reagent With Colorimetric and Fluorogenic Activity, Part II: Optimization, Scope and Limitations, Journal of Forensic Sciences Vol. 50, №6/2005, p. 1367-1371.

44 T. Kent (Ed.), A Manual of Fingerprint Development Techniques (2 ${ }^{\text {nd }}$ Ed.). Revised January 2001, Home Office, Sandridge, UK, 1998. p. 322-343.

45 A. D. Wilkinson, A Study of the Reaction Mechanism of 1,8-Diazafluoren-9-one with the Amino Acid, l-Alanine, Forensic Science International Vol. 109, No 1/2000, p. 87-103. 


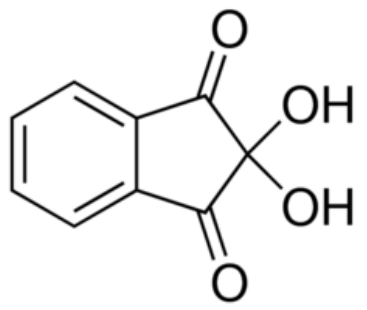

(a)

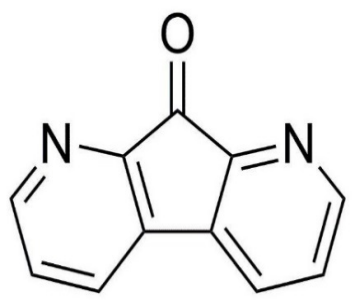

(b)

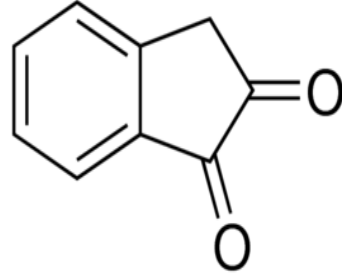

(c)

Figure 7. The chemical structure of ninhydrin, DFO and 1,2-indandione.

1,2-Indandione first came into use in 1997, as a reagent for developing fingerprints on porous surfaces giving the final pink colored product (reminiscent of ninhydrin), while at the same time being fluorescent (reminiscent of DFO). ${ }^{46}$

\section{Some New Systems Used for Latent Fingerprints Detection}

In addition to the foregoing materials, different suspensions based systems also containing cadmium are in use nowadays. Wang et al. ${ }^{47}$ in 2009 addressed the possibility of applying the suspension of photostable cadmium selenide (CdSe) nanoparticles for developing of latent fingerprints on the sticky side of the adhesive, synthesized in an aqueous solution in the presence of mercaptoacetic acid as a stabilizer, ${ }^{48}$ and the results showed that the fluorescence intensity was significantly increased. ${ }^{49}$ The results also showed an increase in the selectivity of this suspension application, while the background noise was at the same time significantly reduced, with better contrast even after $15 \mathrm{~min}$ utes (Figure 8).

46 J. Almog, et al., Latent fingerprint visualization by 1, 2-Indanedione and related compounds: preliminary results, Journal of Forensic Sciences Vol. 44, № 1/1999, p. 114-118.

47 F. Y. Wang, et al., Application of CdSe nanoparticle suspension for developing latent fingermarks on the sticky side of adhesives, Forensic Science International Vol. 185, $\mathrm{N}^{\circ}$ 1/2009, p. 96-99

48 C. Champod,et all., Fingermark Detection and Enhancement, in: Fingerprints and Other Ridge Skin Impressions ( $2^{\text {nd }}$ Ed.). Boca Raton, Florida: CRC press, 2004,p. 174-177 49 F. Y. Wang, et al., The effectiveness of CdSe nanoparticle suspension for developing latent fingermarks, Journal of Saudi Chemical Society, Vol. 13, No 1/2014, p. 13-18 

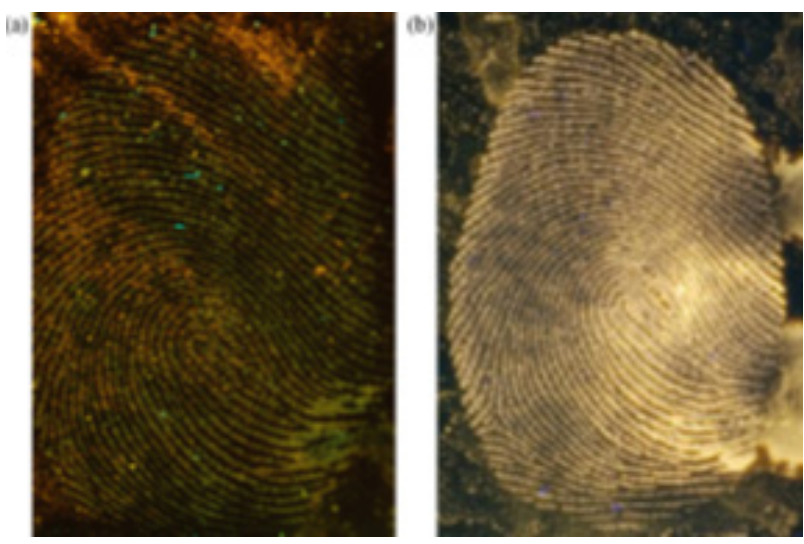

Figure 8. Comparison of fingerprints on the sticky side of the tape treated with different reagents:

(a) before the modification; (B) after modification. ${ }^{50}$

In 2014, the same laboratory examined the possibility of employing suspensions of CdSe for detection of latent fingerprints on non-porous and semi-porous surfaces, ${ }^{51}$ also described by Bécue and Cantú. ${ }^{52}$

\section{Conclusion}

Contemporary detection methods include the use of modern (nano)materials, nanocrystals or nanobelts for developing of latent fingerprints and with high sensitivity, excellent contrast, high selectivity and efficiency, low background noise, and on the various surfaces..$^{53}$ Synthesis and application of these materials requires further improvement of the existing performances, but also provides the possibility for synthesis of entirely new systems for detection of latent fingerprints.

\section{Acknowledgements}

50 F. Y. Wang, et al.,Ibidem, p. 8.

51 F. Y. Wang, et al.,Ibidem, p. 813-18.

52 A. Bécue, A. C. Antonio, Fingermark Detection Using Nanoparticles, in: Lee and Gaensslen's Advances in Fingerprint Technology ( $3^{\text {rd }}$ Ed.). Boca Raton, Florida: CRC press, 2012, p. 327-355.

53 M. Wang, et al., Rare Earth Fluorescent Nanomaterials for Enhanced Development of Latent Fingerprints, ACS Applied Materials \& Interfaces, Vol. 7, № 1/2015, p. 28110-28115. 
The author acknowledges the Ministry of Interior of the Republic of Serbia for financial support to this work within the Project No. 242/16-4-2014 - "Forensic Methods in Criminalistics".

\section{References}

1. Almog, J., Cohen, Y., Azoury. M., Hahn, T. R., Genipin, a novel fingerprint reagent with colorimetric and fluorogenic activity, Journal of Forensic Sciences, Vol. 49, № 2/2004, John Wiley \& Sons, Inc.

2. Almog, J., Springer, E., Wiesner, S., Frank, A., Khodzhaev, O., Lidor, R., Bahav, E., Varkony, H., Dayan, S., Rozen, S., Latent fingerprint visualization by 1,2-Indanedione and related compounds: preliminary results, Journal of Forensic Sciences, Vol. 44, № 1/1999, John Wiley \& Sons, Inc.

3. Altamura, P., Bearzotti, A., D’Amico, A., Foglietti, V., Fratoddi, I., Furlani, A., Padeletti, G., Russo, M.V., Scavia, G., Electrical and morphological characterisation of new $\pi$-conjugated polymer films as gas sensors, Materials Science and Engineering: C, Vol. 5, No 3-4/1998, Elsevier.

4. Araya-Hermosilla, E., Muñoz, D., Orellana, S., Yáñez, A., Olea, A. F., Oyarzun-Ampuero, F., Moreno-Villoslada, I., Immobilization of rhodamine 6G in calcium alginate microcapsules based on aromatic-aromatic interactions with poly(sodium 4-styrenesulfonate), Reactive \& Functional Polymers, Vol. 81, No 1/2014, Elsevier.

5. Bécue, A., and Cantú, A. A., Fingermark Detection Using Nanoparticles, in: Lee and Gaensslen's Advances in Fingerprint Technology (3rd Ed.). Boca Raton, Florida: CRC press, 2012, p. 327-335.

6. Cao, G., Nanostructures and Nanomaterials Synthesis, Properties and Applications, Imperial College Press, UK, 2004, p. 371-372.

7. Champod, C., Fingerprints and other Ridge Skin Impressions. Boca Raton, Florida: CRC Press, 2004, p. 237-244.

8. Champod, C., Lennard, C. J., Margot, P., Stoilovic, M., Fingermark Detection and Enhancement, in: Fingerprints and Other Ridge Skin Impressions (2nd Ed.). Boca Raton, Florida: CRC press, 2004, p. 174-177.

9. Chemical sciences: Polymers for fingerprint analysis, available at: http:// www.natureasia.com/en/research/highlight/9256/ (September 23, 2016.)

10. Chen, Q., Tat Kerk, W., Soutar, A.M., Ting Zeng, X., Application of dye intercalated bentonite for developing latent fingerprints, Applied Clay Science, Vol. 44, No 1-2/2009, Elsevier. 
11. Chowdhury, S. K., Doleman, M., Johnston, D., Fingerprinting Proteins Coupled with Polymers by Mass Spectrometry: Investigation of Polyethylene Glycol-Conjugated Superoxide Dismutase, Journal of the American Society for Mass Spectrometry, Vol. 6, No 1/1995, Springer.

12. Dilag, J., Kobus, H., Ellis, A. V., Cadmium sulfide quantum dot/chitosan nanocomposites for latent fingermark detection, Forensic Science International, Vol. 187, No 1/2009, Elsevier.

13. Fujimoto, B., Clendenning, J., Delrow, J., Heath, P., Schurr, M., Fluorescence and Photobleaching Studies of Methylene Blue Binding to DNA, Journal of Physical Chemistry, Vol. 98, № 26/1994, ACS Publications.

14. Hanus, L. H., Sooklal, K., Murphy, C. J., Ploehn, H. J., Aggregation kinetics of dendrimer-stabilized CdS nanoclusters, Langmuir, Vol. 16, No 1/2000, ACS Publications.

15. http://msdssearch.dow.com/PublishedLiteratureDOWCOM/dh_00ae/0901b803800aea3b.pdf?filepath=surfactants/pdfs/noreg/119-01950. pdf\&fromPage $=$ GetDoc (September 23, 2016.)

16. http://www.crime-scene.com/store/rofin_polilight_flare.shtml (September 23, 2016.)

17. https://www.wou.edu/las/physci/ch350/Projects_2006/Vaandering/Genipin.htm (September 23, 2016.)

18. Islam, N. U., Ahmed, K. F., Sugunan, A., Dutta, J., Forensic Fingerprint Enhancement using Bioadhesive Chitosan and Gold Nanoparticles, Proceedings of the 2nd IEEE International Conference on Nano/Micro Engineered and Molecular Systems, January 16-19, Bangkok, Thailand, 2007, p. 411-415.

19. Issa, M. A., Dueik, I., Morris, G. A., Latent Fingerprint Enhancement Using Tripolyphosphate-Chitosan Microparticles, International Journal of Carbohydrate Chemistry, Volume 2013, Article ID 615124, 4 pages, http:// dx.doi.org/10.1155/2013/615124

20. Jecklin, M. C., Gamez, G., Zenobi, R., Fast polymer fingerprinting using flowing afterglow atmospheric pressure glow discharge mass spectrometry, Analyst, Vol. 134, № 8/2009, Royal Society of Chemistry.

21. Kent, T., (Ed.), A Manual of Fingerprint Development Techniques (2nd Ed.). Revised January 2001, Home Office, Sandridge, UK, 1998, p. 322-343.

22. Lee, H., Advances in Fingerprint Technology (2nd Ed.). Boca Raton, Florida: CRC press, 2001, p. 212.

23. Lee, J., Pyo, M., Lee, S., Kim, J., Ra, M., Kim, W.-Y.., Park, B. J.., Lee, C. W., Kim, J.-M., Hydrochromic conjugated polymers for human sweat pore mapping, DOI: 10.1038/ncomms4736. 
24. Lendlein, A., Jiang, H., Jünger, O., Langer, R., Light-induced shape-memory polymers, Nature, Vol. 434, No 1/2005, Nature Publishing Group.

25. Lennard, C., The Detection and Enhancement of Latent Fingerprints, 13th INTERPOL Forensic Science Symposium, Lyon, France, 2001, p. D288-D2-92.

26. Levinton-Shamuilov, G., Cohen, Y., Azoury, M., Chaikovsky, A., Almog, J., Genipin, a Novel Fingerprint Reagent With Colorimetric and Fluorogenic Activity, Part II: Optimization, Scope and Limitations, Journal of Forensic Sciences, Vol. 50, $\mathrm{N}^{\circ}$ 6/2005, John Wiley \& Sons, Inc..

27. 27. Li, W., Yan, D., Gao, R., Lu, J., Wei, M., Duan, X., Recent Advances in Stimuli-Responsive Photofunctional Materials Based on Accommodation of Chromophore into Layered Double Hydroxide Nanogallery, Journal of Nanomaterials, Article ID 586462, 14 pages, 2013. doi:10.1155/2013/586462.

28. 28. Mastronardi, E., Foster, A., Zhang, X. DeRosa, M., Smart Materials Based on DNA Aptamers: Taking Aptasensing to the Next Level, Sensors, Vol. 14, № 2/2014, Molecular Diversity Preservation International.

29. 29. McCord, B., Forensic Chemistry, Laboratory Manual, Revision 7.1. Department of Chemistry, Florida International University, 2005, p. 48-61.

30. 30. Molapo, K., Ndangili, P., Ajayi, R., Mbambisa, G., Mailu, S., Njomo, N., Masikini, M., Baker, P., Iwuoha, E., Electronics of Conjugated Polymers (I): Polyaniline, International Journal of Electrochemical Science, Vol. 7, No $1 / 2012$, ESG.

31. 31. Payne, G., Reedy, B., Lennard, C., Comber, B., Exline, D., Roux, C., A further study to investigate the detection and enhancement of latent fingerprints using visible absorption and luminescence chemical imaging, Forensic Science International, Vol. 150, № 1/2005, Elsevier.

32. 32. Schnetz, B., Margot, P., Technical Note: Latent fingermarks, colloidal gold and multimetal deposition (MMD) optimization of the method, Forensic Science International, Vol. 118, No 1/2001, Elsevier.

33. Sundarraj, B., Untapped Fingerprint Matching Using Advanced Features, Middle-East Journal of Scientific Research, Vol. 19, No 6/2014, Idosi.

34. T. Kubic; N. Petraco, Forensic Science Manual and Workbook (Revised Ed.). Boca Raton, Florida: CRC press, 2005, p. 43-45

35. Trifkovic, K., Milasinovic, Z., Djordjevic, V., Kalagasidis Krusic, M., Knezevic-Jugovic, Z., Nedovic, V., Bugarski, B., Chitosan microbeads for encapsulation of thyme (Thymus serpyllum L.) polyphenols, Carbohydrate Polymers, Vol. 11, No 1/2014, Elsevier. 
36. Tsai, M. L., Chen, R. H., Bai, S. W., Chen, W. Y., The storage stability of chitosan/tripolyphosphate nanoparticles in a phosphate buffer, Carbohydrate Polymers, Vol. 84, No 2/2011, Elsevier.

37. Wang, M., Li, M., Yu, A., Wu, J., Mao, C., Rare Earth Fluorescent Nanomaterials for Enhanced Development of Latent Fingerprints, ACS Applied Materials \& Interfaces, Vol. 7, № 1/2015, ACS Publications.

38. Wang, Y. F., Yang, R. Q., Shi, Z. X., Liu, J. J., Zhao, K., Wang, Y. J., The effectiveness of CdSe nanoparticle suspension for developing latent fingermarks, Journal of Saudi Chemical Society, Vol. 18, No 1/2014, Elsevier.

39. Wang, Y. F., Yang, R. Q., Wang, Y. J., Shi, Z. X., Liu, J. J., Application of CdSe nanoparticle suspension for developing latent fingermarks on the sticky side of adhesives, Forensic Science International, Vol. 185, No 1/2009, Elsevier.

40. Wilkinson, D. A., A Study of the Reaction Mechanism of 1,8-Diazafluoren-9-one with the Amino Acid, 1-Alanine, Forensic Science International, Vol. 109, No 1/2000, Elsevier.

41. Yu-Juan, J., Yun-Jun, L., Guo-Ping, L., Jie, L., Yuan-Feng, W., Rui-Qin, Y., Wen-Ting, L., Application of photoluminescent CdS/PAMAM nanocomposites in fingerprint detection, Forensic Science International, Vol. 179, $\mathrm{N}^{\circ} 1 / 2008$, Elsevier. 


\title{
POLIMERI U KRIMINALISTICI: OTKRIVANJE LATENTNIH TRAGOVA OTISAKA PRSTIJU - OD IDEJE DO PRAKTIČNE PRIMENE
}

\author{
Nikola Milašinović \\ Kriminalističko-policijska akademija, Beograd
}

Sažetak: Identifikacija latentnih otisaka papilarnih linija od ključne je važnosti za bezbednosne službe u identifikaciji osoba osumnjičenih za izvršenje kriminalnih dela. Latentni otisci ostaju kao slučajni utisci na površinama najrazličitijih objekata. Ogroman napredak je postignut $\mathrm{u}$ identifikaciji pomoću valjanih otisaka prstiju, dok upoređivanje latentnih otisaka ostaje izazov. Pored postojećih, kriminalističkim tehničarima poznatih standardizovanih metoda za otkrivanje i razvijanje latentnih tragova otisaka papilarnih linija, u radu je dat pregled mogućnosti upotrebe prirodnih i sintetskih polimera i njihovih konjugata. Novije metode detekcije uključuju primenu savremenih (nano)materijala, nanokristala i nanokaiševa za razvijanje latentnih otisaka prstiju, sa visokom osetljivošću, dobrim kontrastom, visokom selektivnošću i efikasnošću i niskim pozadinskim šumom, na različitim podlogama. Sinteza i primena svih opisanih materijala zahtevaju dalje poboljšanje performansi već postojećih sistema za detekciju latentnih otisaka papilrnih linija, ali i otvaraju mogućnosti sinteze potpuno novih takvih sistema.

Ključne reči: identifikacija, detekcija i razvijanje latentnih otisaka prstiju i metode detekcije, (bio)polimeri, hitozan. 